\title{
DOI 10.26886/2414-634X.6(42)2020.5
}

\section{UDC 347.635}

\section{CONTENT OF THE RIGHT FOR PROPER PARENTAL NURTURING OF CHILDREN UNDER THE AGE OF 14}

\author{
V. Makovetska \\ e-mail: macovetskaya@i.ua \\ Kharkiv National University of Internal Affairs, Ukraine, Kharkiv
}

Determining the content of the right to proper parental nurturing of children under the age of 14 within the framework of determining the procedure for its implementation and improving the effectiveness of legal regulation of relevant legal relations is an urgent scientific task. The solution to this problem is possible by defining the essence of the relevant subjective right by identifying the needs to be met by parents within the relevant interpersonal impact on a child, and the opportunities to ensure that these needs are met. Based on this analysis, it is proposed to understand the content of the child's rights through a system of powers to recognize the owner of a comprehensive personal intangible asset that mediates the satisfaction of needs in its best interests, through parents to acquire them through parental influence, use their responsibilities to meet their respective needs and demand protection.

Key words: best interests of the child, parental nurturing, basic and higher needs of the child, care and development.

Маковецька В.В. Зміст права на належне батьківське виховання малолітніх осіб / Харківський національний університет внутрішніх справ, Україна, Харків

Визначення змісту права на належне батьківське виховання малолітніх осіб у межах визначення порядку його здійснення та підвищення ефрективності правового регулювання відповідних 
правовідносин є актуальною науковою задачею. Вирішення цієї задачі можливе шляхом визначення сутності відповідного суб'єктивного права через встановлення потреб, які мають бути задоволені батьками у межах відповідного міжособистісного впливу на малолітню дитину, та можливостей, що мають забезпечити задоволення цих потреб. На основі цього аналізу запропоновано розуміння змісту права дитини через систему правомочностей, що полягають у визнанні володільцем комплексного особистого немайнового блага, що опосередковує задоволення потреб згідно з ї найкращими інтересами, завдяки батькам їх набути шляхом сприйняття батьківського впливу, використовувати відповідні блага, вимагати від батьків виконання ними своїх обов'язків із задоволення відповідних потреб та вимагати захисту.

Ключові слова: найкращі інтереси дитини, батьківське виховання, базові та вищі потреби дитини, піклування та розвиток.

Постановка проблеми. Основною метою сімейного законодавства $€$ забезпечення кожної дитини сімейним вихованням, можливістю духовного та фрізичного розвитку. Але саме батьківське виховання надає оптимальну можливість забезпечити малолітній особі нормальний фізичний, морально-етичний, інтелектуальний та соціальний розвиток, дає змогу стати повноцінним членом суспільства. Виховання може мати ознаки належного, і навпаки - не відповідати встановленим у суспільстві критеріям [1, с. 299]. Для визначення шляхів ефрективного здійснення права малолітньої особи на належне батьківське виховання $€$ необхідним встановити зміст цього права. Щодо цього відсутня єдність наукових позицій. Дослідники відзначають, що надати вичерпний перелік його правомочностей складно, оскільки вони мають оціночний характер, одна правомочність може виключати 
іншу (наприклад, батьки беруть участь у вихованні дитини, але вона 3 ними постійно не проживає) та водночас будь-яку з них забезпечувати (сумісне проживання дитини з батьками, їх безперешкодне спілкування сприяє здійсненню виховання); належність батьківського виховання залежить від освіченості, інтелектуального розвитку та матеріального стану сім'ї, в якій виховується дитина [2, с. 175]. Л. А. Савченко зазначає, що конкретний зміст права на належне батьківське виховання чинним законодавством не визначений, що є недоцільним, оскільки неможливо окреслити його межі, що зумовлено тісним переплетінням його правомочностей та батьківських прав [3, с. 15].

Формулювання мети статті та задач. Метою статті $€$ визначення змісту права на належне батьківське виховання малолітніх осіб як суб'єктивного цивільного права.

У доктрині приватного права України зазначене право аналізувалось у межах дослідження батьківських прав або системи прав дитини М. В. Антокольською, Н. Є. Борисовою, Л.В.Красицькою, Б. К. Левківським, Л. А. Ольховик, Н. М. Опольською, О.О.Пундою, Г. О. Різник, Л. А. Савченко, О. В. Синєгубовим, Я. М. Шевченко. Проте не вироблено єдиної позиції щодо змісту права малолітніх осіб на належне батьківське виховання, що $є$ визначальним для порядку його здійснення та захисту, що підкреслює актуальність дослідження.

Виклад основного матеріалу. Зміст права на належне батьківське виховання залежить від його правової природи, яка обумовлена сутністю та змістом суб'єктивного права загалом та особливістю відповідного особистого немайнового блага зокрема.

Суб'єктивне право $є$ мірою можливої поведінки особи, яка опосередкована правомочностями у процесі їх реалізації в структурі правовідносин. Усталеним у доктрині цивільного права $€$ положення, відповідно до якого зміст суб'єктивного права складають три 
правомочності: право на власні дії та дії інших осіб в інтересах одержання певного блага; право вимагати від зобов'язаної особи виконання юридичного обов'язку, що на неї покладено; право на захист своїх повноважень у разі виникнення перешкод реалізації суб'єктивного права [4, с. 11]. У цивілістиці здебільшого підтримується саме цей підхід [5, с. $225 ; 6$, с. $137 ; 1$, с. 197].

О.Є. Казанцева звертає увагу, що зміст суб'єктивного права дитини на виховання полягає у праві вимоги до зобов'язаних осіб у здійсненні ними виховних дій, тобто зміст права переважно складають негативні правомочності: здійснюється шляхом виконання дій зобов'язаною особою. Обов'язки батьків з виховання $є$ мірою необхідної поведінки, яка відображається в особистому впливі батьків чи одного з них на дитину, у зіставленні своїх дій із вимогами педагогіки, норм моралі, правил співжиття та правом 3 метою виховання дитини [7, с. 19-20].

Л.А. Савченко до змісту права дітей на виховання відносить правомочності 3 сімейного навчання, виховання працелюбності, обов'язок батьків дбати про фрізичне та психічне здоров'я, виховання поваги до людської особистості, її прав та основних свобод; навчання дитини дотримуватись положень законодавства, заборону втягнення дитини у злочинну та антигромадську діяльність, насильства щодо дитини [8, с. 18-19]. Відповідні положення $€$ дещо непослідовними, містять мету, межі здійснення права. Л.В. Красицька включає до правомочностей відповідного права одержання піклування про своє здоров'я, фрізичний, духовний та моральний розвиток; здобуття повної загальної середньої освіти; опір неналежному виконанню батьками своїх обов'язків; вимогу поваги до себе. Дослідниця відзначає, що здійснення права на належне батьківське виховання напряму залежить від здійснення права на проживання в сім'ї [4, с. 219-220]. Зокрема, 
відповідно до ст. 11 Закону «Про охорону дитинства» кожна дитина має право на проживання в сім'ї разом із батьками або в сім'ї одного 3 них. Проте, зважаючи на прийняту концепцію змісту суб'єктивного права, ці позиції є неповними [15], а ускладнення визначення змісту досліджуваного права пов'язано не лише з тим, що воно здебільшого реалізується фрактичними способами та способами не регламентованими законодавством (зокрема, методи виховання, повага до дитини, піклування про духовний та моральний розвиток дитини тощо), а законодавством встановлюються лиже «крайні» межі. Причиною також $\epsilon$ те, що належне виховання не може бути реалізоване не тільки без здійснення спеціальних способів, а й інших особистих немайнових прав дитини [1, с. 305], фактично або законом 3 ним безпосередньо поєднаних умовами та метою через дії батьків та наслідки їх невчинення, зокрема: права дітей на контакт з батьками, право на проживання з батьками, визначення місця проживання, права дитини на інформацію, право на врахування думки, право на повну загальну середню освіту.

Зміст права на належне батьківське виховання визначається наявністю можливостей, об'єднаних метою задоволення батьками потреб дитини у нормальному фізіологічному, фрізичному, духовному, психоемоційному, інтелектуальному, безпечному розвиткові. При набутті цих благ $€$ характерним «негативний зміст» права, оскільки самостійне отримання малолітньою особою більшості відповідних особистих немайнових благ $€$ ускладненим через недостатність життєвого досвіду, рівня психологічного розвитку або $€$ взагалі неможливим через ранній вік. Позитивними повноваженнями в межах змісту права на належне батьківське виховання $€$ можливість дитини отримувати особисті немайнові блага, які визначаються безпекою, доглядом, гармонійним інтелектуальним розвитком, нормальним 
психоемоційним станом (сприймати батьківське виховання згідно 3 найкращими інтересами), бути володільцем відповідних благ, використовувати набуті блага на власний розсуд з урахуванням загальних меж здійснення суб'єктивних прав, вимагати належного виховання, чинити опір неналежному вихованню. Негативний зміст права складають дії (іноді - правомірна бездіяльність) батьків щодо піклування, виховання та розвитку.

Способи здійснення негативних правомочностей досліджуваного права визначають зміст обов'язків батьків. Законодавством встановлені орієнтовні критерії, завдяки яким можна встановити, які способи виховання є належними. Критеріями виховання Комітетом міністрів Ради Європи визнано якнайкращий розвиток фрізичних, емоційних, інтелектуальних, соціальних та духовних можливостей дитини, право на повагу до неї як особистості, що має власні права. Критерії виховання та освіти дітей дошкільного віку сформульовані Комітетом міністрів Ради Європи наступним чином: задоволення потреб у безпеці та любові, потреб у суспільному житті, дозвіллі, спілкуванні з іншими дітьми та дорослими; забезпечення умов для міцного фрізичного, розумового здоров'я; стимулювання творчого та інтелектуального розвитку, самовираження; інтеграція в ії середовище та розв'язання життєвих проблеми, заохочування незалежності, ініціативи та вільної гри; повага до культурної, психічної ідентичності дитини та визнання унікальності та індивідуальності; забезпечення середовища для більш широких кіл спілкування, щоб дитина могла зустрічатися з іншими людьми різного віку [9].

Комітет з прав дитини визначив основні критерії оцінки потреб дитини як засобів забезпечення ії̈ найкращих інтересів: турбота, захист та безпека; повага до особистості, віку та статі, персональної історії та соціально-культурного тла, сімейного оточення; забезпечення контактів 
із сім'єю та соціальних контактів 3 однолітками та дорослими; врахування фракторів вразливості, наявності у дитини навичок та розвитку ії здібностей, поглядів та прагнень дитини; прав і потреб у галузі охорони здоров'я, освіти; розвитку дитини, яким визначається перехід у доросле та самостійне життя [10].

Комітет здійснив досить послідовну систематизацію потреб дитини, які визначають блага, що мають бути набутими під час виховання. Загалом класифікація потреб дитини, від яких залежить зміст досліджуваного права може бути здійснена за різними критеріями, але правове значення має диференціація за критерієм незамінності потреб: базові або незамінні мотиви-потреби людини, пов'язані з задоволенням фрізіологічних, матеріально-побутових потреб, зокрема, фрізичного розвитку та здатності до життєдіяльності, безпеки, потреб у любові та приналежності до соціальної групи, розумінні; вищі потреби як мотиви особистісного та духовного зростання, пов'язані 3 фракторами розвитку особистості, пов'язані з моральним, естетичним, інтелектуальним, культурним розвитком, самореалізацією, творенням, підготовкою до самостійного життя, розширенням світогляду, набуттям соціального досвіду, актуалізацією особистісного потенціалу та досягненнями. Задоволення відповідних базових та вищих потреб дітей чинним законодавством України покладено на батьків, за їх наявності, чи осіб, які їх замінюють, через виконання обов'язків у галузі виховання, піклування та розвитку.

Для малолітньої особи на ранніх етапах розвитку фрізіологічні, матеріально-побутові потреби, фрізична безпека та нормальний стан психіки мають виключне значення. Потреба в повазі дитини поряд із доглядом $\epsilon$ першочерговою та визначає разом із фрізичною, психоемоційною безпекою межі права на належне виховання (ч. 1, 6, 7 ст. 150, ч. 3 ст. 151, ч. 1 ст. 155 СК України) [11]. Незадоволення цих 
потреб батьками тягне найсуворіші правові наслідки, що покладено в основу виокремлення підстав позбавлення батьківських прав або відібрання дитини від батьків, а також виокремлення окремої групи способів виконання батьківських обов'язків. Визначальною для малолітньої особи є безпека для життя та здоров'я, що має забезпечитись у сім'ї. $€$ неприпустимим недбале ставлення або жорстоке поводження, створення обставин, які можуть призвести чи призвели до тяжких наслідків для життя, стану здоров'я, тяжкої, зокрема, невиліковної хвороби, тілесних ушкоджень, розвитку дитини, заподіяння шкоди нормальному фрізичному, психічному розвиткові дитини, у зв'язку з чим вона потребує допомоги (абз. 2 п. 2 Порядку забезпечення соціального захисту дітей, які перебувають у складних життєвих обставинах) [12].

Забезпечення систематичної турботи про здоров'я, догляду, здійснення контролю, позитивного впливу на психоемоційний стан та загальний розвиток дитини здійснюється через контакт та спілкування як особисту взаємодію. Право дитини на спілкування з батьками та іншими членами сім'ї визначає умови постійного фрізичного контакту 3 батьками, обміну інформацією. Це підкреслює значення контакту як способу спілкування для дитини та інших способів обміну інформацією, які $€$ вкрай важливими засобами духовного, емоційного, психічного та фрізіологічного розвитку. Водночас це не простий обмін інформацією, а зв'язок біологічної та почуттєвої близькості.

Задоволення метапотреб здійснюється здебільшого через форми та методи виховання, серед яких визначальне значення законом задається сприянню отриманню дитиною повної загальної середньої освіти. До структури права на належне батьківське виховання входять морально-етичний, духовний розвиток дитини, що $є$ вихованням у загальновживаному значенні, здійснюється через спілкування. Батьки 
зобов'язані здійснювати всебічний та гармонійний розвиток дитини, проявляти до неї увагу, надавати моральну підтримку при вирішенні життєвих питань, прищеплювати впевненість у собі та залучати до активної участі у житті суспільства тощо. Моральний розвиток здійснюється шляхом культурного, естетичного (формування «смаків», поглядів на суспільство, природу та людину, творчість) та моральноетичного виховання (засвоєння моральних цінностей, ідеалів, моделей поведінки, традицій та звичаїв)

Окреме значення для морально-етичного виховання має релігійна форма виховання, що характеризується своїми виховними засобами та прийомами. Обрання релігійного виховання $є$ правом батьків. Міжнародний пакт про економічні, соціальні та культурні права зобов'язує поважати свободу обирати для своїх дітей не тільки навчальні заклади державного чи приватного характеру, а й інші школи, що відповідають мінімуму вимог щодо освіти, та забезпечувати релігійне та моральне виховання дітей відповідно до власних переконань [13, с. 186]. Практика ЄСПЛ свідчить про виключне значення цього права у справі «Мансур Йалчын и другие против Турции», у рішенні в якій наголошується на існуванні системної проблеми, зокрема, у турецькій освіті, де не забезпечується повага до релігійного та світоглядного вибору батьків учнів, що визнано порушенням права на освіту [14].

Нормативними актами надається окреме значення соціальному та правому вихованню як способам підготовки дитини до самостійного життя. Воно напряму пов'язано з морально-етичними нормами, що засвоюються малолітньою особою у сім'ї. Відповідно до ст. 12 Закону України «Про охорону дитинства» виховання дитини має спрямовуватися на утвердження поваги до прав, свобод людини і громадянина, мови, національних історичних і культурних цінностей 
українського та інших народів, підготовку дитини до свідомого життя у суспільстві в дусі взаєморозуміння, миру, милосердя, забезпечення рівноправності всіх членів суспільства, злагоди та дружби між народами, етнічними, національними, релігійними групами

Доступ до інформації про реалізації досліджуваного права малолітньою особою залежить від батьків, які, з одного боку, мають надавати доступ у межах, визначених законом та згідно з інтересами дитини, з другого, - сприяти отриманню інформації з метою навчання, розвитку, розширення світогляду та світосприйняття, надавати доступ до інфрормації, яка пов'язана з порядком реалізації та захисту самого права на виховання: прав та обов'язків батьків та дітей, пов'язаних із вихованням, про органи системи державного контролю за належним батьківським вихованням. Право дитини на інформацію не $\epsilon$ елементом права на належне батьківське виховання, є самостійним, але його реалізація впливає на забезпечення інтересів малолітньої особи, які опосередковуються у благах, що забезпечуються батьками при вихованні у зв'язку з неможливістю відокремлення цих благ.

Згідно зі ст. 13 Конвенції про права дитини право вільно висловлювати свої думки є загальним по відношенню до права на пошук, отримання, поширення інформації. У ст. 9 Закону «Про охорону дитинства» закріплений зміст права дитини на вільне висловлення думки та отримання інформації. Праву на висловлення поглядів у ст. 12 зазначеної Конвенції надано окреме значення: дитині, здатній сфрормулювати власні погляди згідно з ії̈ віком і зрілістю, гарантовано право вільно висловлювати ці погляди з усіх питань, що її стосуються [20]. Відповідно до ст. 1 Закону «Про охорону дитинства» забезпечення найкращих інтересів дитини, мають здійснюватись, враховуючи думку дитини, якщо вона досягла такого віку та рівня розвитку, що може ії висловити. У межах засобів виховання має зазначення реалізація 
права малолітньої дитини бути вислуханою та врахування її думки, у чому проявляється батьківське розуміння. При цьому пріоритет має надаватися не принципу врахування думки дитини при прийнятті будьяких рішень щодо неї, а принципу дотримання найкращих інтересів дитини, щодо яких дитина може висловлюватись.

До правомочностей дитини за чинним законодавством у межах права на належне батьківське виховання відноситься вимога до батьків в отриманні освіти, сприяння отриманню освіти. Батькам же належить право вибору виховного або освітнього закладу. Водночас у ч. 3 ст. 150 СК України встановлено, що батьки зобов'язані забезпечити здобуття дитиною повної загальної середньої освіти. Оскільки малолітні особи внаслідок незрілості не мають змоги всебічно оцінити свої можливості та потреби, відповідальність за їх освіту та навчання покладено на батьків. Освіта $є$ важливою формою соціалізації, отримання знань для визначення напряму здійснення соціально корисної праці при самостійному житті. Право дитини на підготовку до самостійного життя $€$ елементом соціально-економічного виховання. Обов'язок батьків забезпечити здобуття повної загальної середньої освіти $€$ мінімальним рівнем здійснення розумового виховання (турбота батьків про отримання дітьми знань, формування потреби їх отримувати) [21, c. 107-108], що охороняється законом, є критерієм для оцінки батьківського виховання як належного.

Мотивація до навчання та його успішність напряму залежить від позитивних аспектів стилю виховання, який переважає в сім'ї, атмоссрери сімейного оточення. Тому закономірним $є$ те, що на батьків покладено обов'язок забезпечити здобуття дитиною повної загальної середньої освіти, чим одночасно здійснюється підготовка дитини до самостійного життя. Водночас у межах обов'язків батьків щодо освіти дитини йдеться не про успішність оволодіння дитиною певними 
знаннями, а про дії, що свідчать про те, що батьки розуміють її важливість для майбутнього самостійного життя малолітньої дитини.

Враховуючи розуміння потреб та особливостей розвитку дитини у ранньому, дошкільному, молодшому шкільному віці, не можна не відзначити про необхідність забезпечити малолітній дитині відпочинок та дозвілля. Окреме значення в межах можливостей дитини, на реалізацію яких вона має розраховувати при батьківському вихованні це розвиток природніх здібностей. Відповідно до ст. 12 Закону «Про охорону дитинства» батьки зобов'язані створювати належні умови для їх розвитку, мають виявляти здібності, сприяти розвитку здібностей та обдарувань дитини, задоволенню інтересів, духовних запитів і потреб у профресійному визначені. Зокрема, може йтись про сприяння участі дитини в дитячих змаганнях, фестивалях, наукових виставках, учнівських олімпіадах та конкурсах, екологічних, технічних, мистецьких, туристичних, дослідницьких, спортивних заходах (ч. 5 ст. 157 СК України). Водночас, зважаючи на зміст батьківського виховання, незадоволення цих потреб не характеризує його як неналежне, але має бути оцінено у сукупності з іншими обставинами для визначення якості батьківського впливу або ступеню участі кожного з батьків у розвиткові при захисті права малолітньої дитини на належне батьківське виховання.

Отже, найкращі інтереси дитини обумовлюють отримання виховного впливу різної направленості в межах форм та методів, які здатні сфрормувати гармонійну, фізично та психічно здорову особистість, здатну без ускладнень здійснювати процес міжособистісної та масової комунікації. Дитина має розраховувати та те, що обрані батьками методи та форми виховання (передання на виховання, залучення до виховання інших осіб, сімейне, релігійне, 
шкільне виховання, різні стилі виховання у сім'ї тощо), будуть забезпечувати її найкращі інтереси.

«Неправильне виховання» обумовлюється різноманітними причинами: соціально-економічними, моральними, юридичними, психолого-педагогічними. Вони впливають на поглиблення проблем батьківського виховання $[18$, с. 25]. Неналежне виховання дитини $€$ головною причиною десоціалізації особистості малолітньої особи, є підґрунтям негативних поглядів та звичок, негативно впливають на засвоєння дитиною норм поведінки [17]. На противагу цьому «теплий» сімейний клімат, заснований на особистісній фрормі спілкування батьків та дітей, формує у малолітніх осіб високу сприйнятливість до виховного впливу загалом, сприяє збереженню почуття власної гідності, яке вже виникло, що стає потребою, яку $є$ необхідним задовольнити для психічного здоров'я дитини [16, с. 93]. Ці положення психологічних досліджень ще раз підтверджують міркування про взаємозалежність піклування та турботи із морально-етичним, духовним й інтелектуальним розвитком, підготовкою до самостійного життя, що обумовлює батьківське виховання як комплексне особисте немайнове благо. Враховуючи те, що правова охорона надається належному вихованню, до його загально-педагогічних умов можна віднести особистий приклад батьків, їхній авторитет, глибоке та всебічне знання батьками особливостей та потреб своїх дітей, організацію спільної діяльності, вільного часу, спілкування з дітьми, а також єдність вимог членів сім'ї [19, с. 111-115].

Незважаючи на очевидний виховний потенціал авторитетного стилю виховання, українським законодавством не встановлено для батьків модель відповідного виховного впливу. Авторитарний та ліберальний стиль виховання (відчуження, уникнення, надмірне оберігання, надмірна вимогливість тощо як негативні прояви 
батьківського ставлення) за певних умов можна визнаватись неналежним вихованням, що дає підстави дитині противитись вихованню. Правомочності з захисту досліджуваного права можуть бути реалізовані малолітньою особою особисто, зокрема, через опір неналежному вихованню, одним із батьків для захисту від неналежної поведінки іншого з батьків, членами сім'ї, визначеними в законі, та органами державної влади. Право чинити опір неналежному вихованню безпосередньо пов'язано із правом дитини на висловлення та врахування ії думки. Ці положення мають особливе значення при вирішенні судами справ щодо виховання, визначають необхідність використовувати результати психологічних досліджень. Застосовувані батьками методи мають бути поряд із іншими його аспектами ґрунтовно дослідженні при вирішенні питання про порушення прав малолітніх осіб з метою встановлення наявності негативного впливу на стан та якості дитини, її здоров'я, розвиток, забезпечення інших особистих немайнових прав дитини.

Висновки. Право малолітньої особи на належне батьківське виховання $€$ засобом задоволення ії потреб у набутті комплексу особистих немайнових благ та особистих якостей, необхідних для нормальної життєдіяльності та соціалізації, які дитина не може отримати самостійно, враховуючи закономірності вікового фрізичного, психічного та соціального становлення. Потреби, засобом задоволення яких $є$ право малолітньої особи на належне батьківське виховання, узагальнено за критерієм їх незамінності.

Зміст права на належне батьківське виховання складають можливості малолітньої особи визнаватись володільцем комплексного особистого немайнового блага, що опосередковує задоволення зазначених потреб згідно з ії найкращими інтересами, завдяки батькам їх набути шляхом сприйняття батьківського впливу, використовувати 
відповідні блага, вимагати від батьків виконання ними своїх обов'язків із задоволення відповідних потреб та вимагати захисту. Зміст правомочностей 3 набуття благ у структурі права залежить від диференціації потреб. Відповідно визначення змісту досліджуваного права дитини на належне батьківське виховання обумовлює форми батьківського виховання: піклування, морально-етичне, духовне, інтелектуальне виховання, розвиток та підготовка до самостійного життя. Забезпечення реалізації правомочностей 3 піклування та підготовки до самостійного життя заходяться під особливою охороною держави. У межах правового регулювання надається значення стилям, формам, методам, засобам, меті та завданням виховного впливу, які підпорядковані найкращим інтересам дитини, моральним засадам суспільства, перспектива дослідження яких визначається необхідністю встановлення порядку реалізації досліджуваного права та встановленням критеріїв його ефективної охорони та захисту.

\section{תimepamypa:}

1. Синєгубов, О.В. (2015). Здійснення особистих немайнових прав осіб, що не досягли повноліття. Харків.

2. Синєгубов, О.В. (2014). Тлумачення права на належне батьківське виховання в контексті його здійснення неповнолітньою особою. Науковий вісник Ужгородського національного університету. Серія: Право, 27, 172-175.

3. Савченко, Л.А. (1997). Про права і обов'язки батьків по вихованню дітей. Право України, 5, 55-57.

4. Красицька, Л.В. (2014). Проблеми здійснення та захисту особистих та майнових прав батьків і дітей. Київ: Ліра-К. 
5. Кузнєцова Н.С., Харитонов Є.О., Майданик Р.А. (2013). Правова доктрина України: у 5 т. Т. 3: Доктрина приватного права України. Харків: Право.

6. Стефранчук, Р.О. (2007). Особисті немайнові права фрізичних осіб у цивільному праві (поняття, зміст, система особливості здійснення та захисту). Хмельницький: Видавництво Хмельницького ун-ту управління та права.

7. Казанцева, А.Е. (1987). Обязанности и права родителей (заменяющих их лиц) по воспитанию детей и ответственность за их нарушение. Томск: Изд-во Томского университета.

8. Савченко, Л.А. (1997). Особисті права та обов'язки батьків $і$ дітей за сімейним законодавством України. Київ.

9. Про виховання та освіту дітей від народження до восьмирічного віку, 1981 (Комітет міністрів Ради Європи). Офріційний сайт Верховної Ради України. <https://zakon.rada.gov.ua/laws/show/994_730> (2020, липень, 02).

10. General comment on the right of the child to have his or her best interests taken as a primary consideration, 2013. UN Committee on the Rights of the Child. <https://www.refworld. org/docid/51a84b5e4.html> (2020, вересень, 12).

11. Сімейний кодекс, 2002. (Верховна Рада України). Офріційний сайт Верховної Ради України. <https://zakon.rada.gov.ua/laws/show/294714/print\#n1576> (2020, серпень, 07).

12. Про забезпечення соціального захисту дітей, які перебувають у складних життєвих обставинах, 2020 (Кабінет Міністрів України). Ооріиійний сайт Верховної Ради України. <https://zakon.rada.gov.ua/laws/show/585-2020-\%D0\%BF\#n13> (2020, серпень, 08). 
13. Стешенко, В.М. (2019). Правовий захист прав дітей та підлітків $і$ безпечний інфрормаційний простір. Харків : Лисенко І. Б.

14. Мансур Йалчын (Mansur Yalcin) u другие против Турции Постановление, 2014, <http://www.consultant.ru/cons/cgi/ online.cgi?req=doc $\&$ base $=A R B \& n=418545 \# 03104360065036398>(2020$, вересень, 23).

15. Закон про охорону дитинства, 2001 (Верховна Рада України). Ооріційний сайт Верховної Ради України. <https://zakon.rada.gov.ua/go/2402-14> (2020, липня, 03).

16. Вопросы психологии ребенка дошкольного возраста (1995): сборник статей (Редкол.: А.Н. Леонтьева, А.В. Запорожца). Москва: Международный образовательный и психологический коледж.

17. Дідківська, Г.В. (2016). Криміногенність сімті як фрактор злочинності неповнолітніх. Київ: Центр учбової літератури.

18. Выготский, Л.С. (1984). Собрание сочинений в 6 m. Т.2. Вопросы общей психологи. Москва.

19. Пунда, О.О. (2005) Право на сімейне виховання та проблеми його здійснення. Вісник Запорізького національного університету. Юридичні науки, 1, 111-115.

20. Конвенція про права дитини: 1982 (Організація Об'єднаних Націй). Офріційний сайт Верховної Ради України. <http://zakon.rada.gov.ua/laws/show/995_021> (2020, липня, 24).

21. Радченко, Н. В. (2017). Право дитини на сімейне виховання. Вісник Черкаського національного університету імені Богдана Хмельницького. Серія: Педагогічні науки, 7, 103-108.

\section{References:}

1. Synjegubov, O.V. (2015). Zdijsnennja osobystyh nemajnovyh prav osib, shho ne dosjagly povnolittja [Exercise of personal non-property rights of minors]. Harkiv. [in Ukrainian]. 
2. Synjegubov, O.V. (2014). Tlumachennja prava na nalezhne bat'kivs'ke vyhovannja $v$ konteksti jogo zdijsnennja nepovnolitn'oju osoboju. [Interpretation of the right to proper parental upbringing in the context of its implementation by a minor]. Naukovyj visnyk Uzhgorods'kogo nacional'nogo universytetu [Scientific Bulletin of Uzhhorod National University. Pravo], no. 27, 172-175. [in Ukrainian].

3. Savchenko, L.A. (1997). Pro prava i obov'jazky bat'kiv po vyhovannju ditej [About the rights and responsibilities of parents in raising children]. Pravo Ukrai'ny [Law of Ukraine], 5. 55-57. [in Ukrainian].

4. Krasyc'ka, L.V. (2014). Problemy zdijsnennja ta zahystu osobystyh ta majnovyh prav bat'kiv $i$ ditej [Problems of realization and protection of personal and property rights of parents and children]. Kyi'v, Lira-K. [in Ukrainian].

5. Kuznjecova N.S., Harytonov Je.O., Majdanyk R.A. (2013). Pravova doktryna Ukrai'ny: u 5 t. T. 3: Doktryna pryvatnogo prava Ukrai'ny [Legal doctrine of Ukraine: in 5 vols. Vol. 3: Doctrine of private law of Ukraine]. Harkiv, Pravo. [in Ukrainian].

6. Stefanchuk, R.O. (2007). Osobysti nemajnovi prava fizychnyh osib u cyvil'nomu pravi (ponjattja, zmist, systema osoblyvosti zdijsnennja ta zahystu) [Personal non-property rights of individuals in civil law (concept, content, system of features of implementation and protection)]. Hmel'nyc'ky]: Vydavnyctvo Hmel'nyc'kogo un-tu upravlinnja ta prava. [in Ukrainian].

7. Kazanceva, A.E. (1987). Objazannosti i prava roditelej (zamenjajushhih ih lic) po vospitaniju detej i otvetstvennost' za ih narushenie [Duties and rights of parents (substitutes) for the upbringing of children and responsibility for their violation]. Tomsk : Izd-vo Tomskogo universiteta. [in Russian]. 
8. Savchenko, L.A. (1997). Osobysti prava ta obov'jazky bat'kiv i ditej za simejnym zakonodavstvom Ukrai'ny [Personal rights and responsibilities of parents and children under the family law of Ukraine]. Kyi'v. [in Ukrainian].

9. Pro vyhovannja ta osvitu ditej vid narodzhennja do vos'myrichnogo viku 1981 (Komitet ministriv Rady Yevropy). [On the upbringing and education of children from birth to eight years 1981 (Committee of Ministers of the Council of Europe)]. Ofitsiynyy sayt Verkhovnoyi Rady Ukrayiny. [The official website of the Verkhovna Rada of Ukraine]. Retrieved from https://zakon.rada.gov.ua/laws/ show/994_730>. [in Ukrainian]. (2020, july, 02).

10. General comment on the right of the child to have his or her best interests taken as a primary consideration, 2013. UN Committee on the Rights of the Child. Retrieved from https://www.refworld. org/docid/51a84b5e4.html [in English]. (2020, july, 03).

11. Simeinyi kodeks 2002 (Verhovna Rada Ukrai'ny). [Family Code 2002 (Verkhovna Rada of Ukraine)]. Ofitsiynyy sayt Verkhovnoyi Rady Ukrayiny. [The official website of the Verkhovna Rada of Ukraine]. Retrieved from https://zakon.rada.gov.ua/laws/show/2947-14 [in Ukrainian]. (2020, august, 08).

12. Pro zabezpechennia sotsialnoho zakhystu ditei, yaki perebuvaiut $u$ skladnykh zhyttievykh obstavynakh 2020 (Kabinet Ministriv Ukrainy). [On ensuring social protection of children in difficult life circumstances 2020 (Cabinet of Ministers of Ukraine)]. Ofitsiynyy sayt Verkhovnoyi Rady Ukrayiny. [The official website of the Verkhovna Rada of Ukraine]. Retrieved from https://zakon.rada.gov.ua/laws/show/585-2020\%D0\%BF\#n13 [in Ukrainian]. (2020, august, 08).

13. Steshenko, V.M. (2019). Pravovyi zakhyst prav ditei ta pidlitkiv $i$ bezpechnyi informatsiinyi prostir [Legal protection of the rights of children 
and adolescents and a secure information space] Kharkiv : Lysenko I. B. [in Ukrainian].

14. Mansur Jalchyn (Mansur Yalcin) i drugie protiv Turcii 2014 [Mansur Yalcin and Others v. Turkey Decree, 2014]. Retrieved from http://www.consultant.

$\mathrm{ru} /$ cons/cgi/online.cgi? req=doc\&base=ARB\& $\mathrm{n}=418545 \# 0310436006503639$ 8 [in Russian]. (2020, september, 23). [in Russian].

15. Zakon Pro okhoronu dytynstva 2001 (Verhovna Rada Ukrai'ny) [Law on Child Protection 2001 (Verkhovna Rada of Ukraine)]. Official site of the Verkhovna Rada of Ukraine [The official website of the Verkhovna Rada of Ukraine]. Retrieved from https://zakon.rada.gov.ua/go/2402-14 [in Ukrainian]. (2020, july, 03). [in Ukrainian].

16. Voprosy psihologii rebenka doshkol'nogo vozrasta 1995: sbornik statej (Redkol.: A.N. Leont'eva, A.V. Zaporozhca) [Collection of works in 6 vols. Vol.2. Questions of psychology of the child of preschool age: collection of articles. (Editor: A.N. Leontiev, A.V. Zaporozhets)]. Moscow: International Educational and Psychological College. Moskva: Mezhdunarodnyj obrazovatel'nyj i psihologicheskij koledzh. [in Russian].

17. Didkivska, H.V. (2016). Kryminohennist simi yak faktor zlochynnosti nepovnolitnikh [Family criminogenicity as a factor in juvenile delinquency]. Kyiv: Tsentr uchbovoi literatury. [in Ukrainian].

18. Vygotskij, L.S. (1984). Sobranie sochinenij v 6 t. T.2. Voprosy obshhej psihologi. [Collection of works in 6 vols. Vol.2. Questions of general psychologists]. Moskva. [in Russian].

19. Punda, O.O. (2005) Pravo na simeine vykhovannia ta problemy yoho zdiisnennia [The right to family education and problems of its implementation]. Visnyk Zaporizkoho natsionalnoho universytetu. Yurydychni nauky [Bulletin of Zaporizhia National University. Legal sciences], no. 1, 111-115. [in Ukrainian]. 
20. Konventsiia pro prava dytyny 1991 (Organizacija Ob'edinennyh Nacij) [Convention on the Rights of the Child 1991 (United Nations)]. Ofitsiynyy sayt Verkhovnoyi Rady Ukrayinyn [The official website of the Verkhovna Rada of Ukraine]. $\quad$ Retrieved from http://zakon.rada.gov.ua/laws/show/995_021 [in Ukrainian]. (2020, june, 24). [in Ukrainian].

21. Radchenko, N.V. (2017). Pravo dytyny na simeine vykhovannia [The child's right to family upbringing]. Visnyk Cherkaskoho natsionalnoho universytetu imeni Bohdana Khmelnytskoho. Seriia: Pedahohichni nauky [Bulletin of Cherkasy National University named after Bohdan Khmelnytsky. Series: Pedagogical sciences], no. 7, 103-108. [in Ukrainian].

Citation: V. Makovetska (2020). CONTENT OF THE RIGHT FOR PROPER PARENTAL NURTURING OF CHILDREN UNDER THE AGE OF 14. New York. TK Meganom LLC. Innovative Solutions in Modern Science. 6(42). doi: 10.26886/2414-634X.6(42)2020.5

Copyright: V. Makovetska (C). 2020. This is an openaccess article distributed under the terms of the Creative Commons Attribution License (CC BY). The use, distribution or reproduction in other forums is permitted, provided the original author(s) or licensor are credited and that the original publication in this journal is cited, in accordance with accepted academic practice. No use, distribution or reproduction is permitted which does not comply with these terms. 